(С) Ю.Г. Лобода, 2012

ISSN 2076-8184. Інформаційні технології і засоби навчання. 2012. №2 (28).

УДК 378.013+371.334

Режим доступу до журналу: http://www.journal.iitta.gov.ua

Лобода Юлія Геннадіївна, кандидат педагогічних наук, доцент кафедри комп’ютерних систем і управління бізнес-процесами, Одеська національна академія харчових технологій, м. Одеса, e-mail: jul.loboda@gmail.com

\title{
ЕЛЕКТРОННІ ЗАСОБИ НАВЧАННЯ: СТРУКТУРА, ЗМІСТ, КЛАСИФІКАЦІЯ
}

\author{
Анотація \\ У статті проаналізовано проблеми організації навчального процесу 3
} використанням електронних засобів навчання. Уточнюється дефініція електронних засобів навчання, їх структура i зміст. Розглядаються дидактичні принципи, які покладені в основу їх створення i застосовування. Детально охарактеризовані електронні засоби навчання за методичним призначенням. На підставі виділених педагогічних завдань використання електронних засобів навчання представлена i доповнена їх класифікація, а саме, засоби теоретичної і технологічної підготовки, засоби практичної підготовки, допоміжні засоби, комплексні засоби.

Ключові слова: засоби навчання, електронні засоби навчання, класифікація, дидактичні принципи.

Постановка проблеми. У системі вищої професійної освіти відбуваються суттєві зміни. Вступають в силу нові державні освітні стандарти, у яких, крім змісту освіти, знайшли відображення і зміни в організації навчальної роботи ВНЗ: аудиторної і самостійної. Відповідно до цих стандартів відбувається перерозподіл навчального навантаження: зменшення годин аудиторних занять i відповідно збільшення частки самостійної роботи студентів. У зв'язку з цим для забезпечення і підвищення якості освітнього процесу поряд із традиційними засобами навчання необхідно розробляти і застосовувати сучасні інформаційно-комунікаційні технології. Розв'язанням цього завдання може стати впровадження в освітній процес електронних засобів навчання. Проблема організації навчального процесу 3 використанням електронних засобів навчання надзвичайно актуальна, вона дозволяє здійснити перехід від предметного принципу побудови змісту освіти до створення інтегрованих навчальних курсів. На перше місце виходять не просто знання, уміння застосовувати ці знання для розв'язання різноманітних життєвих, професійних 
проблем. Якість освіти тепер пов'язують із поняттям конкурентоспроможності фахівця, його компетентністю, що, у першу чергу, передбачає вміння працювати 3 інформацією, приймати самостійні обгрунтовані рішення.

Аналіз досліджень і публікацій. Проблема використання засобів навчання у педагогічній теорії і практиці не є новою. До неї зверталися багато вчених і практиків, вона була предметом дослідження Л. Данилевича, А. Денисова, В. Казанського, П. Підкасистого, О. Трофимова та ін. Найбільш грунтовно і повно сутність електронних засобів навчання й особливості їх використання у процесі професійної підготовки фахівців у вищій школі розглянуто i конкретизовано в роботах О. Башмакова, І. Богданової, Л. Боднар, М. Жалдака, Н. Макоєд, І. Мархеля, С. Полат, Д. Чернилевського, І. Роберт, Є. Сарафанюка, О. Хуторського, М. Челишкової.

Метою статті $\epsilon$ аналіз різних підходів до визначення поняття "електронні засоби навчання", їх класифікація, структура, зміст, принципи створення i застосовування.

Виклад основного матеріалу. Інтерпретацію поняття "засоби навчання" можна знайти в науковій психолого-педагогічній і технічній літературі. Так, на думку П. І. Підкасистого, засоби навчання - це матеріальні й матеріалізовані предмети, які викладач застосовує для викладання навчального матеріалу [1]. Засоби навчання - це наочна підтримка навчального процесу, якою є мова викладача, його майстерність, підручники, аудиторне устаткування [2, с. 295].

О. М. Спірін вважає, що використання електронних матеріалів має особливі властивості, цінні для ефективної організації суспільного життя: невичерпність, велику швидкість розповсюдження, економічність, екологічну чистоту, значну тривалість зберігання за незначних ресурсних витрат тощо. Сучасні засоби опрацювання даних i зв'язку $\epsilon$ основою нових інформаційно-комунікаційних технологій, які все більше визначають зміст, масштаби і темпи розвитку інших технологій [3, с. 14].

У класифікації електронних засобів навчання використовуються різні підходи: технічні, програмні, ергономічні, психолого-педагогічні тощо. У межах кожного підходу класифікація характеризує засоби навчання з тієї чи іншої позиції, яка визначає деякі їх властивості, але не характеризує педагогічних можливостей засобів навчання загалом. 
Детально схарактеризував електронні засоби навчання Д. В. Чернилевський: "Електронні засоби навчання - програмні засоби навчального призначення, у яких відображена певна предметна галузь, у тій або іншій мірі реалізована технологія іiі вивчення, забезпечені умови для реалізації різних видів навчальної діяльності" [4, с. 369]. На думку вченого, електронні засоби навчання, що використовують у навчальних цілях за методичним призначенням, можна класифікувати так:

- навчальні програмні засоби - призначені для узагальнення суми знань, формування вмінь i навичок навчальної або практичної діяльності, а також забезпечення необхідного рівня засвоєння, що встановлюється під час зворотного зв'язку;

- програмні засоби (системи) - тренажери, призначені для відпрацьовування вмінь, навичок навчальної діяльності, самопідготовки;

- $\quad$ контрольні програмні засоби - призначені для контролю (самоконтролю) рівня оволодіння навчальним матеріалом;

- інформаційно-пошукові програмні системи, інформаційно-довідкові програмні засоби - призначені для формування вмінь і навичок із систематизації інформації;

- $\quad$ імітаційні програмні засоби - призначені для вивчення певного аспекту реальності, його основних структурних або функціональних характеристик за допомогою обмеженою кількості параметрів;

- $\quad$ моделюючі програмні засоби - призначені для створення моделі об'єкта, явища, процесу або ситуації (як реальних, так і "віртуальних") з метою їх вивчення;

- демонстраційні програмні засоби - призначені для наочного подання навчального матеріалу, візуалізації досліджуваних явищ, процесів і взаємозв'язку між об'єктами;

- навчально-ігрові програмні засоби - призначені для "програвання" навчальних ситуацій;

- $\quad$ дозвільні програмні засоби - призначені для організації позааудиторної роботи, що мають на меті розвиток уваги, реакції, пам'яті тощо.

Згідно МОН України, електронні засоби навчального призначення - засоби навчання, що зберігаються на цифрових або аналогових носіях даних і відтворюються на електронному обладнанні (комп'ютерні програми загальнодидактичного 
спрямування, електронні таблиці, електронні бібліотеки, слайдтеки, тестові завдання, віртуальні лабораторії тощо). Електронні засоби загального призначення - засоби навчання, що зберігаються на цифрових або аналогових носіях даних і відтворюються на електронному обладнанні й забезпечують підтримку інноваційних технологій навчання (операційні системи, прикладні програми, автоматизовані системи управління, бази даних тощо) [5].

Ми розуміємо, електронні засоби навчання як програмні продукти, що створені i працюють 3 використанням комп'ютерної, телекомунікаційної техніки, i забезпечують творче й активне опанування майбутніми фахівцями знаннями, уміннями і навичками, необхідними в майбутній професійній діяльності.

Принципи створення і застосовування електронних засобів навчання детально розглянуті в працях українських і російських учених. В основу застосовування електронних засобів навчання покладені такі основні дидактичні принципи:

- принцип наочності навчання - передбачає використання в процесі навчання різноманітних засобів наочної демонстрації навчальної інформації, зокрема образотворчих засобів (малюнків, фотопортретів, фоторепродукцій картин, живопису, архітектури та інших фотозображень навколишнього світу), умовно-графічних засобів (таблиць, схем, блок-схем, креслень, графіків, діаграм, карт, картосхем тощо), сучасних мультимедія (аудіо- і відеофрагментів, анімації);

- принцип розподілу навчального матеріалу - передбачає, що навчання, основане на комп'ютерних технологіях, базується на технічній інфраструктурі: комп'ютері (як інструменту для розміщення і демонстрації навчальної інформації), комп'ютерних мережах (як засобу доступу до неї). Тому, електронні засоби навчання можуть знаходитися безпосередньо у студента, у межах локальної мережі (Інтранетресурси) або розміщені на серверах глобальної мережі Інтернет (Інтернет-ресурси);

- принцип інтерактивності навчального матеріалу -передбачає інтеграцію різних засобів демонстрації інформації таких як текст, статична і динамічна графіка, відео- і аудіозаписи, у єдиний комплекс, що дозволяє студентові стати активним учасником навчального процесу; замість розрізнених навчальних програм повноту демонстрації матеріалу забезпечують цілісні інтерактивні курси;

- принцип мультимедійної репрезентації навчальної інформації передбачає максимальне врахування індивідуальних особливостей сприйняття 
інформації завдяки мультимедія;

- принцип адаптивності до персональних особливостей студента передбачає варіювання обсягу інформації, пропонованої для вивчення за певний проміжок часу, залежно від індивідуальних особливостей студента; у зв'язку з цим основною проблемою оптимізації навчання 3 точки зору збереження i розвитку адаптаційних резервів є оцінка і корекція стану людини в процесі здобуття нових знань.

Принципи організації навчального процесу 3 використанням електронних засобів навчання відображені в наказах МОН "Про правила використання комп’ютерних програм в навчальних закладах" [6], постанові Кабінету Міністрів Україні "Про затвердження Державної програми "Інформаційні та комунікаційні технології в освіті та науці"" [7].

Метою організації навчального процесу з використанням електронних засобів $€$ :

- упровадження інформаційних і комунікаційних технологій;

- забезпечення реалізації прав на вільний пошук, отримання, передавання, виробництво та поширення інформації;

- виконання покладених на навчальні заклади освітянських завдань підготовки необхідних спеціалістів i кваліфікованих користувачів в умовах формування інформаційно-освітнього і культурного середовища;

- сприяння розвитку вітчизняного виробництва високотехнологічної продукції, насамперед - конкурентоспроможних комп'ютерних програм як найважливішої складової інформаційних і комунікаційних технологій, сприяння переходу економіки на інноваційний шлях розвитку.

Електронні засоби навчання $€$ засобами, спеціально створеними для розв’язання педагогічних завдань, їх основне призначення - використання в навчальному процесі. До електронних засобів навчання можна віднести текстові й графічні редактори, компілятори і системи програмування, системи автоматизованого проектування, експертні системи, іншими словами - усі засоби, що кваліфікують як предмет вивчення або як інструментарій у розв'язанні освітніх завдань.

Слушним є погляд російського ученого О. І. Башмакова, який виокремлює основні завдання, що розв'язуються за допомогою електронних засобів навчання, а 
came [8]:

- $\quad$ початкове ознайомлення 3 предметною галуззю, освоєння іiі базових понять і концепцій;

- базова підготовка на різних рівнях глибини і детальності;

- $\quad$ вироблення вмінь і навичок розв'язання типових практичних завдань у певній предметній галузі;

- вироблення вмінь аналізу й ухвалення рішень у нестандартних проблемних ситуаціях;

- $\quad$ розвиток здібностей до певних видів діяльності;

- $\quad$ проведення навчально-дослідних експериментів 3 моделями об'єктів, що вивчають, процесів і середовища діяльності;

- $\quad$ контроль й оцінювання рівнів знань і вмінь.

Усі ці завдання мають інтегральний характер, їх розв’ язання впливають один на одне, тому види електронних засобів навчання здебільшого уналежнюють до корелюючих завдань.

Спираючись на виокремленні вище педагогічні завдання, О. І. Башмаков пропонує поділити електронні засоби навчання на чотири класи [8, с. 24]. Розглянемо детальніше види електронних засобів навчання за кожним класом.

Перший клас електронних засобів навчання - засоби теоретичної i технологічної підготовки:

- електронний підручник - основне електронне видання, створене на високому науковому і методичному рівнях, яке повністю відповідає Державному освітньому стандарту певних спеціальностей [9];

- $\quad$ комп'ютерна навчальна програма - призначена для навчання найважливіших розділів дисципліни, використовують для проведення групових занять у комп'ютерних класах і для ефективної організації самостійної роботи;

- $\quad$ комп'ютерна система контролю знань - визначення рівня знань 3 певної дисципліни, розділу, теми або фрагменту предметної галузі й оцінювання 3 урахуванням встановлених кваліфікаційних вимог.

Другий клас електронних засобів навчання - засоби практичної підготовки:

- електронний задачник - засіб для вироблення вмінь i навичок розв’язання типових практичних завдань, а також розвитку пов'язаних 3 ними 
здібностей;

- комп'ютерний тренажер - пристрій, у якому як модель об'єкта управління, так і робоче місце студентів й інструктора реалізовані завдяки комп'ютерним засобам.

Третій клас електронних засобів навчання - допоміжні засоби:

- комп'ютерний лабораторний практикум - засіб підтримки автоматизованих лабораторних робіт, у межах яких об'єкти, що вивчаються, процеси i середовище діяльності використовують за допомогою експериментів з їх моделями;

- $\quad$ комп'ютерний довідник - інформаційна база за певною дисципліною, що забезпечує можливість використовувати їі в навчальному процесі;

- мультимедійне навчальне заняття - мультимедійний запис реального навчального заняття, лекції, семінару або демонстрації.

Четвертий клас електронних засобів навчання - комплексні засоби:

- $\quad$ комп'ютерний навчальний курс для підготовки за певною дисципліною, у якому інтегровані функції або засоби для розв’язування основних завдань теоретичної, технологічної і практичної підготовки.

Ми доповнюємо класифікацію електронних засобів навчання. Висновки представимо на рис. 1. 


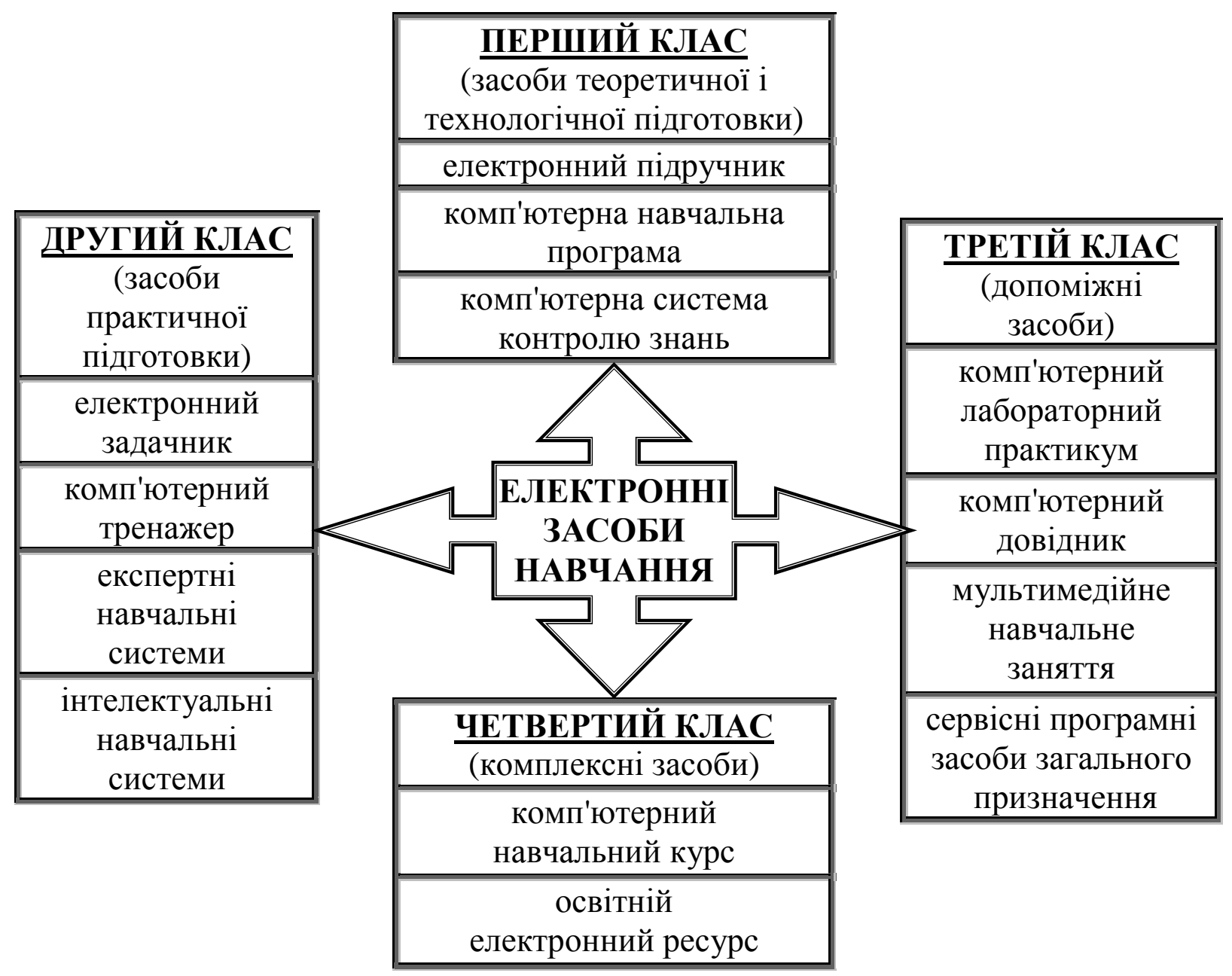

Рис. 1. Класифікація електронних засобів навчання

Другий клас електронних засобів навчання:

- $\quad$ експертні навчальні системі реалізуються на базі ідей і технологій штучного інтелекту, моделюють діяльність експертів під час розв'язування досить складних завдань 3 певної предметної галузі, забезпечують пояснення стратегії і тактики розв'язування завдань у ході діалогової підтримки процесу розв'язування;

- інтелектуальні навчальні системі відносяться до систем найбільш високого рівня, реалізуються на базі ідей штучного інтелекту, можуть здійснювати управління на всіх етапах розв'язування навчальної задачі, починаючи від іiі постановки (постанова, пошук принципу розв'язання й оцінка оптимальності розв'язання 3 урахуванням особливостей діяльності студентів), забезпечують діалогову взаємодію, водночас у ході діалогу може обговорюватися правильність дій, стратегія пошуку розв'язання, планування дій, прийоми контролю тощо.

Взагалі експертні системи $є$ різновидом систем прийняття рішень, і з цієї точки зору, їх можна віднести до класу інтелектуальних систем підтримки прийняття 
рішень. Інтелектуальні навчальні системи не обов'язково пов'язанні 3 підтримкою прийняття рішень, або з навчанням у галузі прийняття рішень. Можна вважати інтелектуальні навчальні системи більш широким поняттям, ніж експертні навчальні системи. Інтелектуальні навчальні системи не обов’язково спираються на досвід експертів або на обробку отриманих від експертів даних.

Третій клас електронних засобів навчання:

- $\quad$ сервісні програмні засоби загального призначення застосовуються для автоматизації рутинних обчислень, оформлення навчальної документації, обробки даних експериментальних досліджень, використовуються під час проведення лабораторних, практичних занять, в організації самостійної і проектної роботи студентів.

Четвертий клас електронних засобів навчання:

- електронний освітній ресурс - сукупність засобів програмного, інформаційного, технічного, організаційного забезпечення, електронних видань, що розміщуються на електронних носіях і/або в мережі.

На думку С. А. Іванченко, за нинішнього зростання потоків наукової інформації репродуктивне засвоєння студентами необхідного обсягу знань стає неможливим. За таких умов головним завданням професійної підготовки стає навчити майбутнього фахівця здобувати, обробляти та зберігати отриману інформацію й ефективно використовувати ii у професійній діяльності, що потребує залучення сучасних технологій до роботи студентів під керівництвом викладача, самостійної роботи студентів у лабораторіях, обладнаних комп'ютерами і доступом до мережі Інтернет, роботи на об'єктах майбутньої професійної діяльності [10].

Висновки. Проведений аналіз наукової літератури показав, що існуючі підходи до розгляду питання використання електронних засобів навчання тією чи іншою мірою розкривають різні теоретичні основи. Представлення навчальної інформації за допомогою електронних засобів навчання дозволяють отримати максимальний ефект у засвоєнні матеріалу, так як під час роботи з такого роду засобами активізуються всі види розумової діяльності, правильно побудований навчальний процес, 3 урахуванням психолого-педагогічних особливостей, дає можливість досягти необхідної якості навчання. 


\section{Список використаних джерел}

1. Педагогика : учебн. пособие [для студентов педагогических вузов и педагогических колледжей] / под ред. П. И. Пидкасистого. - М. : Педагогическое общество России, 1998. - 640 с.

2. Подласый И. П. Педагогика. Новый курс : учебник для студ. пед. вузов: [в 2 кн.] / Иван Павлович Подласый. - [Кн. 1: Общие основы. Процесс обучения]. - М. : Гуманит.изд.центр ВЛАДОС, 1999.- 576 с.

3. Cnipiн O. M. Теоретичні та методичні засади професійної підготовки майбутніх учителів інформатики за кредитно-модульною системою : монографія / О.М. Спірін; [за наук. ред. акад. М. І. Жалдака]. - Житомир : Вид-во ЖДУ ім. I. Франка, 2007. - 300 с.

4. Чернилевский Д. В. Дидактические технологии в высшей школ : учеб. пособие для вузов / Дмитрий Владимирович Чернилевский. - М. : ЮНИТИ-ДАНА, 2002. - 437 с. - (Серия "Педагогическая школа: XXI век").

5. Про затвердження Порядку надання навчальній літературі, засобам навчання і навчальному обладнанню грифів та свідоцтв Міністерства освіти і науки України. Наказ Міністерства освіти і науки України від 17 червня 2008 року № 537. Режим доступу : http://www.ukrbook.net/zakony/N_537.htm.

6. Міністерство освіти і науки України. Наказ. м. Київ. № 903 від 02 грудня 2004p. Про затвердження Правил використання комп'ютерних програм у навчальних закладах. - Режим доступу : http://www.mon.gov.ua/laws/MON_903.doc.

7. Кабінет Міністрів України. Постанова. Програма. Заходи. Від 07.12.2005 № 1153. Про затвердження Державної програми "Інформаційні та комунікаційні технології в освіті і науці" на 2006-2010 роки. - Режим доступу : http://zakon.rada.gov.ua/cgi-bin/laws/main.cgi?nreg=1153-2005-\%EF.

8. Башмаков А. И. Разработка компьютерных учебников и обучающих систем : монография / А. И. Башмаков, И. А. Башмаков. - М. : Информационноиздательский дом "Филинъ", 2003. - 616 с.

9. Дьяченко М. И. Психология высшей школы / М. И. Дьяченко, Л. А. Кандыбович. - [2-е изд., перераб. и доп.]. - Минскм: Изд-во БГУ, 1981. - 383 с.

10. Іванченко $Є . A$. Аналіз результатів функціонування системи інтегративної професійної підготовки майбутніх економістів [Електронний ресурс] 
/ Є. А. Іванченко // Інформаційні технології і засоби навчання. - 2009. - № 3(11). Режим доступу до журн. : http://www.ime.edu-ua.net/em11/emg.html.

\section{ЭЛЕКТРОННЫЕ СРЕДСТВА ОБУЧЕНИЯ: СТРУКТУРА, СОДЕРЖАНИЕ, КЛАССИФИКАЦИЯ}

Лобода Юлия Геннадьевна, кандидат педагогических наук, доцент кафедры компьютерных систем и управления бизнес-процессами, Одесская национальная академия пищевых технологий, г. Одесса, e-mail: jul.loboda @ gmail.com

\section{Аннотация}

В статье проанализированы проблемы организации учебного процесса с использованием электронных средств обучения. Уточняется дефиниция "электронные средства обучения", их структура и содержание. Рассматриваются дидактические принципы, которые положены в основу их создания и применения. Дана подробная характеристика электронных средств обучения по методическому назначению. На основании выделенных педагогических задач использования электронных средств обучения представлена и дополнена их классификация, а именно: средства теоретической и технологической подготовки, средства практической подготовки, вспомогательные средства, комплексные средства.

Ключевые слова: средства обучения, электронные средства обучения, классификация, дидактические принципы.

\section{E-LEARNING TOOLS: STRUCTURE, CONTENT, CLASSIFICATION}

Yuliya G. Loboda, $\mathrm{PhD}$ (pedagogical sciences), associate professor of the Department of computer systems and business process management, Odessa National Academy of Food Technologies, Odessa, e-mail: jul.loboda @ gmail.com

\section{Resume}

The article analyses the problems of organization of educational process with use of electronic means of education. Specifies the definition of "electronic learning", their structure and content. Didactic principles are considered, which are the basis of their creation and use. Given the detailed characteristics of e-learning tools for methodological purposes. On the basis of the allocated pedagogical problems of the use of electronic means of education presented and complemented by their classification, namely the means of 
theoretical and technological training, means of practical training, support tools, and comprehensive facilities.

Keywords: learning tools, e-learning tools, classification, didactic principles.

Матеріал надійшов до редакції 12.03.2012 p 